\title{
Understanding the Success of Government Portals: The Role of Political Leadership, Standards, and a Powerful Centralized IT Agency
}

\author{
J. Ramon Gil-Garcia \\ University at Albany, SUNY \\ United States \\ jgil-garcia@ctg.albany.edu
}

\author{
Evelyn Vargas-Marin \\ Facultad Latinoamericana de \\ Ciencias Sociales, Argentina \\ mina.vm@gmail.com
}

\author{
Mila Gascó \\ University at Albany, SUNY \\ United States \\ mgasco@ctg.albany.edu
}

\begin{abstract}
Information technologies have become an essential component of government administrative reforms and governance strategies around the world. Although Internet portals are now some of the most mature technologies, they continue to be the most important channel for governments to provide information and services to citizens and other stakeholders. However, studies about government portals still lack the level of detail necessary to better understand the specific variables that affect their success and, more prominently, how these variables intertwine. Based on institutional theory, particularly the technology enactment framework, and one in-depth case study in Mexico, this paper shows how leadership from the governor, the establishment of government-wide rules and standards, and the existence of a powerful centralized IT agency collectively affect the process of enacting a state government website and its potential results. The paper also identifies other variables and discusses some of their interactions and mechanisms of influence.
\end{abstract}

\section{Introduction}

In the last decade, government portals have become one of the main sources of government information and services (Angoitia, 2007). Government portals are integrated online windows that provide both external and internal users with a single point of access for information and services (Luna-Reyes, HernándezGarcía, \& Gil-Garcia, 2009). In practice, most of these websites are managed by a single government agency responsible for IT, but their construction and the provision of information requires the involvement of multiple and very diverse agencies. For instance, each agency selects their own content and prepares the information and services they want to offer via the portal (Thomas \& Alalwan, 2016).

The central IT agency coordinates activities and works with the other agencies in this process. This central IT agency can be organized into several departments that collect, classify, and consolidate information for the portal. Working with the other agencies, which are the content owners, these IT departments help to create content before it is displayed on the government portal.

As previously mentioned, a government portal is considered a single window that integrates services from multiple agencies with different users and approaches (Gil-Garcia, Chengalur-Smith, \& Duchessi, 2007; Gil-García \& Dawes, 2007). The portals are particularly interesting because of the necessary level of coordination and collaboration among multiple government agencies. The portals and their respective processes could be designed and organized in order to provide information and services according to the needs of citizens, rather than being organized around the structure of government (Angoitia, 2007).

Some benefits from government portals are cost savings, increased efficiency, better service quality, improved transparency and accountability, and reduced response times (Sandoval-Almazán \& Gil-García, 2008). In addition, portals can improve service delivery, strengthen communication, and promote participation and collaboration among government agencies and with citizens (Gil-García, 2013). Finally, portals can foster political participation and the involvement of citizens in government decisions (Sandoval-Almazán \& Gil-García, 2008). Portals are enduring technologies that have not yet been replaced. Over the years, however, governments have adopted more tools and applications, such as web 2.0 tools and social media, some of which are now integrated into their overall strategies and portals.

Although portals have been studied for over a decade, it is still not clear what makes them successful (Management Association, 2015). Particularly, what is the combination or combinations of variables that influence the success of government portals and how are they interrelated? Based on an in-depth case study, this paper contributes to this discussion by highlighting the collective importance of political leadership, government-wide standards, and a centralized IT 
agency for the development and management of a successful portal.

The paper is organized in six sections, including the foregoing introduction. Section two briefly explains the technology enactment framework as one integrated approach to the study of digital government from an institutional perspective. Section three describes the research design and methods used for this study. This research is based on an in-depth case study, including semi-structured interviews and document analysis. Section four presents the main results of our analysis and section five discusses these results and identifies some practical and theoretical implications. Finally, section six provides some concluding remarks and suggests areas for future research on this topic.

\section{Institutional Theory and the Technology Enactment Framework}

The analytical framework proposed by Fountain (2001) explicitly incorporates information technology into an institutional perspective. Technology enactment refers to how government organizations use, perceive, and/or design information technologies (Duhamel, Gutiérrez-Martínez, Picazo-Vela, \& Luna-Reyes, 2014). Fountain (2013) explains that similar units within a government can use identical information systems and still obtain completely different results.

Institutions and organizations affect the adoption of information technology and influence perception, objective design, and use of technologies such as the Internet and various pieces of hardware and software (Luna-Reyes \& Gil-Garcia, 2014). Technologies, at the same time, can influence and reshape organizations and institutions, thereby affecting their efficiency, effectiveness, and transparency. Technology and institutional arrangements affect each other as a result of the actions and decisions of political actors (Fountain, 2013).

According to technology enactment theory, technology is enacted by government organizations and is affected by political, social, economic, and organizational aspects. Institutional arrangements and organizational characteristics influence the adoption, implementation, and use of information technologies (Ahn \& Berardino, 2014; Fountain, 2013). Subsequent studies, like Gil-Garcia (2012), build on this framework of technology enactment and propose some elaborations and extensions. This and other integrative analytical frameworks are important to better understand the success factors of e-government initiatives (Bwalya, Zulu, Grand, \& Sebina, 2012; Madsen \& Kræmmergaard, 2016).
While Fountain (2001) observed organizations, GilGarcia (2012) also analyzes individuals who work within government agencies. His extended framework also takes into account the environment to understand how contextual factors influence the enacted technology and, consequently, the organizational results. Below, we briefly describe the main variables or constructs of the technology enactment framework and how they affect the success of e-government.

\subsection{Organizational Characteristics and Management Processes}

The extended model proposed by Gil-Garcia (2012) acknowledges the importance of how organizations are structured in terms of size, hierarchy, and business processes, and includes the individuals who work in those government organizations. In addition to more enduring organizational characteristics, it is also important to analyze management strategies and practices, which can significantly affect the success of e-government.

Technological devices are designed, built, and used by people; these people have different interpretations of social reality based on their formal education, professional background, and past experiences (GilGarcia, 2012). Therefore, technology is affected by the interests, values, and assumptions of a wide variety of individuals and groups, including public managers, developers, and users. The leadership of these stakeholders is an important variable to consider (Criado, Gascó, \& Jiménez, 2010).

\subsection{Institutional Arrangements}

When public managers make decisions, they need to consider a large number of laws and regulations (Criado et al., 2010; Gil-Garcia, 2012). Institutional arrangements are mainly conceived as laws, regulations, standards, and accepted cultural behaviors that affect digital government projects (Mercado-Lara \& Gil-García, 2014). They affect how public managers select, design, implement, or use information technologies (Fountain, 2013).

More generally, institutional arrangements are laws, regulations, and other cognitive, cultural, or socio-economic rules found in the context of government agencies (Fountain, 2001). From this perspective, organizational factors have a direct impact on the enacted technology, while institutional arrangements directly affect organizational factors and indirectly influence the characteristics of the technology (Gil-García, 2012). Therefore, there are multiple relationships among organizations, institutions, and information technologies.

\subsection{Contextual Factors}


For digital government projects, the economic, political, and social contexts are very important (GilGarcía, 2012). Contextual factors influence organizational characteristics and management strategies. Some of these factors could also affect institutional arrangements and indirectly influence the enacted technology (Sáez Martín, Rosario, \& Pérez, 2016).

\subsection{Results}

Potential results from technology implementation include cost savings, increased efficiency, improved effectiveness, better organizational control, and/or improved operational integration (Gil-García, 2012; Susanto \& Aljoza, 2015). However, government managers can reduce or increase their expectations for technology in alignment with their focus for egovernment implementation. Portals can be a tool for a more fluid and less costly communication channel between government and citizens to allow greater participation or transparency (Noveck, 2009; Mercado-Lara \& Gil-García, 2014).

More than a decades ago, Heeks (2003) argued that the implementation of e-government projects is not simple, and it is estimated that up to 85 percent of such projects fail in developing countries. This high failure rate was a clear indication that there was a need to better understand the variables that affect the successful implementation of this type of project. Today, good progress has been made, but there is still a lack of detail in terms of how different sets of variables affect e-government success and how they are interrelated in specific contexts.

\section{Research Design and Methods}

This study is part of a larger project that analyzes how organizational and institutional variables affect the success of government portals in Mexico. The overall research project includes the study of several cases and this paper reports the results of one of them, which is the government-wide portal of the State of Mexico. The case was selected based on its relative success, represented by the Index of State Electronic Government (IGEE), which assesses the portals of the 31 states and the Federal District in Mexico. The State of Mexico won first place in the 2010 ranking, improving from fourth place in the 2009 ranking. In 2011, the portal fell to sixth place, but in 2012 it rose once again to be in second place.

After an analysis of the organizational chart of the state government, we decided to focus our research on the Informatics State System (SEI in Spanish), which is an agency similar to a state CIO in the US. We interviewed the Chief Officer of the SEI, the head of the Department of Technology Infrastructure Management, and the head of the Department of Telecommunications, but all other interviewees were from the Electronic Government Department and Information Technology Policy Department, both of which were responsible for the portal and coordination with other state agencies.

With the support of SEI, the research team conducted semi-structured interviews with people who have a role in the administration and development of the portal. We used a snowball strategy (Brayda \& Boyce, 2014) to identify additional potential interviewees in the General Directorate of SEI. This paper uses a purposeful sample of key informants with prior experience and involvement with the state portal and the network of agencies managing it. Following a theoretical saturation logic, we continued adding interviews until new units did not provide new data as useful evidence for this study.

The interviews were conducted at the end of 2012 and the questionnaire was based on the technology enactment framework (Fountain, 2001; Gil-Garcia, 2012). The questionnaire included questions about several categories, including the background of the interviewee, characteristics of the portal, institutional arrangements, organizational structures and processes, the internal and external environment, and the results, benefits, and achievements of the portal. Since SEI is responsible for management of the portal, most of our interviews were with public managers working in this agency.

\section{Analysis and Results}

This section presents the results of our analysis. The section is organized according to the main theoretical constructs of the technology enactment framework and evidence is provided for each component.

\subsection{Enacted Technology}

The portal for the State of Mexico was established in 1996. Originally it was a simple site designed to provide basic information about tourism, the economy, vehicle ownership taxes, and how to obtain copies of birth certificates. Initially there was no agency responsible for the integration and coordination of efforts; each agency handled its own website and there was no regulation or approval of content. This initial use of technology resources showed limited links using HTML and excessive flash effects.

In June 2007, there was a change in the management of the portal, by order of then Governor of the State of Mexico, Enrique Peña Nieto, who 
developed an integrated portal and asked all state ministries to put at least one service online. One of the main objectives was for each agency to provide at least one service that was online from start to finish, where the citizen did not have to stop and physically retrieve an end product from that agency.

To accomplish this goal, the General Directorate of the Informatics State System (SEI) was created under the Secretary of Finance. SEI was responsible for working on the design and architecture of the web portal, as well as organizing the joint efforts of all agencies under the integrated portal. While some agencies already had websites, the structure of many sites and the language used was difficult for citizens to navigate. Therefore, one of SEI's primary objectives was to create the portal using language that was accessible and understandable for citizens.

Before SEI became the manager of the portal, the process for building the site was chaotic because there were public managers who wanted to upload information individually, making the portal oversaturated. Over time, the portal began to support interactive media, social media, and e-services thanks to tools that streamlined services for citizens. One ongoing improvement is the redesign of the portal with search functions so that citizens can locate information or a specific program by topic, rather than by agency.

Since the SEI budget is limited, they have decided to use open source software to enhance the functionality and interactivity of the portal. They also use social media and interviewees consistently said that these channels have great potential for government to build a closer relationship with its citizens and to meet their needs. SEI also made long-term technology decisions. For instance, servers were purchased with sufficient storage for many years and some interviewees from SEI believe that these long-terms strategies have helped them with their day-to-day work.

The portal of the State of Mexico uses Oracle Content Management technology and the programming language is Java. It has test environments and production. In the beginning, the site was created in HTML, but as the site received increased demand SEI had to change the technology. After HTML, SEI began to use an Oracle Portal in 2007 to manage the agency websites and subsequently migrated to Oracle Content Management in 2009, although some sites were retained in HTML.

Because SEI is responsible for coordinating the different government agencies to integrate their online presence, they had to consider different platforms for the varying knowledge levels of the team. Portal construction was a challenge for several public managers who were forced to approach the technology and above all rethink the processes that operate in their physical offices so that they could provide them to citizens through the portal. According to the logic of the State of Mexico's government, portals were a tool for achieving an open and transparent government, encouraging freedom of information and for anyone to access the services offered.

The defining characteristics of the portal are quality information of interest to the public and the use of interactive and social media, all delivered in language that is understandable to the public. Today, the site is a joint effort by different areas of state government, which are responsible for the information they publish. The main objectives of the portal are to improve the experience of citizens in relation to their government through procedures that promote better quality public services, transparency, and citizen participation.

\subsection{Portal Services and Results}

The result of all these efforts can be seen in the portal today, which provides a range of services intended to enable citizens to easily complete transactions. The information is presented by theme: agriculture, arts and culture, science and technology, education, environment, regulations, fees and taxes, health, safety, tourism, urban planning, housing, and participation. The portal is also divided into eight sections that represent different user profiles: public managers, elderly, indigenous, youth, women, migrants, disabled people, and children. The portal provides three types of services, listed in the table below.

Table 1. Types of services.

\begin{tabular}{|c|c|}
\hline Online Services (Procedures) & $\begin{array}{l}\text { Enable the provision of services } \\
\text { from beginning to end without } \\
\text { visiting a physical office. This } \\
\text { was expected to reduce costs for } \\
\text { the user and to allow for the } \\
\text { decentralization of services. }\end{array}$ \\
\hline Online Consultations & $\begin{array}{l}\text { Enable the user to view } \\
\text { information without providing } \\
\text { their data, so that they can } \\
\text { access continually updated } \\
\text { information about the agencies } \\
\text { and their services. }\end{array}$ \\
\hline $\begin{array}{l}\text { Online Advising or Specialized } \\
\text { Counseling }\end{array}$ & $\begin{array}{l}\text { Enable users to perform } \\
\text { specialized queries or send } \\
\text { specific questions. The user } \\
\text { must provide their name and } \\
\text { email to receive a reply. }\end{array}$ \\
\hline
\end{tabular}

Within its first two years, the portal was able to manage a number of procedures from start to finish; as of our interviews, there were 160 electronic transactions available. Via the portal, citizens can receive information about processing requirements for 
a range of transactions and may be directed to the payment gateway for payment and receipts.

One of the major changes to the portal was the ability to make payments electronically, which helps to avoid fraud and the misappropriation of funds, but some interviewees mentioned that there are still some departments that resist this change in process. In addition, the portal has a system for citizens to propose improvements to the site through an online suggestion box. SEI is responsible for reviewing such requests and channels them to the appropriate agencies. The portal allows agencies to communicate with citizens. The first efforts were through chats, forums, blogs, and surveys, but more recently include social media. SEI also posts contact information for the webmaster at each agency.

There are some agencies, such as the Directorate of Innovation, that are not part of SEI, but do fall under the Secretary of Finance and therefore collaborate with SEI. This collaboration provides a great network for the construction of helpful portal features. These features include the provision of complementary services, like the toll-free call center and an online chat feature, both of which answer questions about online services and are available during periods when there is the greatest user demand.

The result of all these efforts is a portal that allows transparency, access to information, and a communication channel for government that is open to citizens 24 hours a day. Citizens want to know the programs their government offers, including scholarships, social support, and registrations, and the portal is the place where they can go for full details about these programs. Public managers can make better assessments about employee interactions with citizens that take place via the portal, as well as manage the human resources (such as payroll and vacation/sick leave) in their agency.

The portal is a reliable tool that helps the state government to be informed about what citizens, businesses, and public managers need. The payment gateway supports transparency, while citizens benefit from reduced transportation times and costs associated with accessing services in person. Overall, the portal is a network of agencies that must be coordinated to provide a single face to the citizen; the enacted technology is affected by the dynamics that exist in each of the units.

\subsection{Organizational Structures and Processes}

This section will explain how the portal is organizationally structured, including the stakeholders and agencies involved in its construction, how decisions are made, and how they communicate across the physical offices, in order to understand how all these factors have affected the portal of the State of Mexico.

\section{General Organizational Characteristics}

As previously mentioned, SEI is an agency under the Secretary of Finance of the State of Mexico and its main functions are to promote the use of information technologies intended to automate processes, streamline services and procedures, and make management more efficient in state government offices. Another function of SEI is updating the information-related regulations of the executive branch, which requires coordination with some of its units such as the Directorate of Electronic Government and Information Technology Policy. SEI is also continuously in contact with all the units that feed information to the portal. The SEI is not involved at the municipal level because they are autonomous entities independent from the state, but it can impose some regulations on municipalities.

SEI has one general director and four directorates with different activities: (1) Directorate of Electronic Government and Information Technology Policy, in charge of the portal of the State of Mexico; (2) Directorate of Information Engineering, responsible for monitoring the technological components of the portal; (3) Directorate of Technology Infrastructure Management, with data center managers who are responsible for monitoring the objective technology, including oversight of the call center and database; and lastly (4) Directorate of Telecommunications, which is in charge of Internet support and security.

All of these directorates are very important for the functionality of the portal, but this study focused on the Directorate of Electronic Government and Information Technology Policy, since this is the organization that is directly responsible for oversight of the portal. This Directorate is composed of a team of 17 people who administer the government-wide website of the State of Mexico. Within the team there is little turnover and they are unionized and trusted employees.

This Directorate provides services to the governor, 17 secretaries, several decentralized agencies, and also receives requests from the federal government. Their daily activities include updating news, events, and announcements on the portal. They also conduct random monitoring of agency websites to see if they have updated their information. The Directorate of Electronic Government and Information Technology Policy includes three departments: (1) Department of Contents, (2) Department of Marketing and Portal Design, and (3) Department of Electronic Services.

The Department of Contents has four staff members and their responsibilities are to create information architectures and content for the portal and 
to manage interactive media and social media. The Department of Marketing and Portal Design has a staff of eight people who interact with the offices of regulated agencies and entities, including municipalities, to whom SEI provides support to build their own websites. Finally, the Department of Electronic Services has a staff of four people who develop a methodology to improve processes and streamline services.

Under the Directorate of Electronic Government and Information Technology Policy is the SubDirectorate of Information Technology Policy with a team of five people. One of the responsibilities of the Sub-Directorate of Information Technology Policy is to monitor compliance with the guidelines of portal development. The Sub-Directorate has three departments: (1) the Department of Monitoring, (2) the Department of Project Assessment and Support for Committees, and (3) the Department of Procedures and Services. The Department of Monitoring is dedicated to the definition of public policies and digital policies. The Department of Project Assessment and Support for Committees has a team of six people who are responsible for reviewing all requests for acquisition of information technology to evaluate whether the technology is suitable for the administrative unit that requests it. The Department of Procedures and Services is arguably the most important of the units because they evaluate and deliver services to the citizens.

The Directorate of Electronic Government and Information Technology Policy is interconnected with other agencies such as the Internal Comptroller, which has a specialized information technology area to ensure SEI's compliance with regulations and to monitor the portal's services. The Comptroller is also responsible for verifying that the applications citizens submit online are handled in a timely fashion.

There is another major player in the development of the portal: the Office of Social Communication at the Governor's Office. They define the institutional and political image for the State of Mexico; the Directorate of Electronic Government and Information Technology Policy then adapts the portal and web environment to that vision. The Directorate always needs the approval of the Office of Social Communication before new information is published on the portal, since it represents the state government and the governor to citizens.

The Directorate is continuously in contact with all the agencies that feed information to the portal. SEI provides and enables spaces within the site for each of the information owners to add their content in the appropriate place. Some interviewees alluded to complications that arose when they built the portal and public managers working at the Directorate mentioned age differences and differing skills among different team members, which they overcame by dividing the activities based on background, knowledge, and skill levels.

For the construction of the portal, there were also challenges with coordinating the external agencies that feed the portal. The main challenge mentioned by individuals within the SEI was the change of view required of the public managers at the participating agencies, who now needed to see the portal as the dissemination tool for their programs. The second challenge was to coordinate the delivery of information in a timely manner. It is noteworthy that SEI only supports, but has no authority over, the other agencies and has no clear enforcement mechanisms to ensure that they deliver information in a timely manner.

\section{Management Strategies and Practices}

Public managers working for SEI are experts in technology; most have training in information technology or have developed professional experience in this area, whether their knowledge is more technical or managerial. Almost all the interviewed public managers within SEI had prior experience working within government. SEI has very diverse responsibilities that require public managers to use different skills, processes, and strategies (see Figure 2).

\section{Figure 2. Activities under the responsibility of SEI}

(1) Administer the website.

(2) Design the strategy and the corresponding structure of the portals and government websites for the State of Mexico.

(3) Select the technology tools for the portal.

(4) Design the interface of the portal and all the features, components, and graphic elements for use on the portal and across all websites of the state executive.

(5) Provide technological support to all of the agencies that feed the portal.

(6) Provide links across the portal, for both citizens and agencies.

(7) Establish the rules and guidelines for the portal that all agencies must adopt.

(8) Define guidelines for the development of the portal in accordance with state political priorities.

(9) Review the content of published materials to ensure agencies are meeting the set standards.

(10) Manage the portal's infrastructure, including databases, email, the electronic signature system, dot net development, and Java updates.

To feed the portal, SEI needs the support of other agencies to provide information to citizens. When an agency's leaders want to develop their section, SEI representatives meet with them to define the target audience and the strategy for the site, providing research on similar national and international sites. Agencies are then responsible for providing expertise and generating information for the site. Depending on the capabilities within the agency, SEI will also propose social media channels that might be appropriate for the agency to use on the portal. 
The individual agencies can decide if they want to develop their section of the portal with the Directorate of Electronic Government and Information Technology Policy or with their own in-house human and technological resources, but the latter requires that the Internal Comptroller oversees the process. When agencies develop their site on the portal, the Directorate monitors the normative parts-design, image, and structure- to ensure they adhere to the established standards.

Once the agencies have their pages and online services posted they have an obligation to maintain them, which requires that they continue to communicate with the Directorate. In order to make changes, the agencies need to communicate those plans to the Directorate, whether in a written memo, an email, or even an informal conversation. The Directorate must approve any changes that modify the structure of the page and SEI has a technological liaison with a password required to update any information. As we have seen throughout this section, SEI has multiple strategies and processes that help with its responsibilities related to portal development and management. In addition, its position under the Secretary of Finance and its regulatory power seems to also contribute to a more coordinated network of agencies and a better portal for citizens.

\subsection{Institutional Arrangements}

During the interviews, we inquired about the rules, regulations, and laws governing the State of Mexico's website to better understand how decisions are made and what behaviors are acceptable. All agencies involved in the portal are aligned with the State Development Plan, and the portal is an important point within that plan because it is a tool for interaction, accountability, and service delivery, all of which provide value to citizens. The State Development Plan has a digital section that indicates the importance of this public policy area for the state and that provides the blueprint for the e-government program. The Plan establishes technology as a tool to help the state achieve goals such as economic development, enhanced justice, and the creation of a knowledge society.

Each governor generates her or his own State Development Plan. During Enrique Peña Nieto's term, the main objective was to improve procedures; with the change to Governor Eruviel Avila, the emphasis shifted to increased use of social media. As mentioned in previous sections, the transaction and interaction components for the State of Mexico were among the best scores in the rankings, which shows how technological leadership from the governor affects the enacted technology.
Most interviewees noted that there were no major changes to their jobs when the governor changed. They justified this lack of change based on the legal framework that allows them to maintain continuity in the civil service. As a result, there were changes in the prioritization of projects, but not in the ways of operating. It is noteworthy, however, that the same political party remained in government during this transition, which could also be part of the explanation for that stability.

The Directorate of Electronic Government and Information Technology Policy is responsible for generating regulations regarding the appearance of the websites that feed the portal, which they validate with the Informatics Policy Branch of the legislature. In addition to these regulations, the Peña Nieto administration established an internal policy for the State of Mexico's provision of services, which emphasizes the use of technologies for online service delivery. These guidelines define the basic structure of the sites to establish the placement of the headers and footers, margin type, content, and the style of the websites.

In addition, SEI's Department of Contents developed a manual of citizen language, which establishes plain language for use on all government websites to avoid jargon. There are also guidelines for interactive media that serve to guide departments in the appropriate use of a chat, a forum, or a blog. There is also a policy for social media use that specifies who is authorized to use social media to interact with citizens.

Among the most frequently mentioned federal laws, federal election law was prominent because it requires some specific content not to be published during elections periods. For some units, this restriction of citizen access to portal content during that time of the elections was a negative aspect of the law. Other relevant federal laws include the administrative code that defines administrative procedures and the financial codes that dictate how the state can allocate and spend resources.

Apart from existing regulations, some interviewees from SEI had worked on the development of a legal framework for electronic media that would enable wider use of technology for public services. This new law defines the use of electronic signatures and electronic seals so that they would have the same legal validity as an in-person procedure with a written signature or stamped seal. It is remarkable that the State of Mexico was able to address electronic signatures within the context of its public administration, and this state law was then taken into consideration by the federal government to generate its own. 
Security and privacy guidelines were passed into law in September 2010, which are meant to ensure the proper handling and use of citizen information, including security mechanisms related to both technology and policy. In this area, however, most interviewees believe the state still has an opportunity to improve. Overall though, the institutional arrangements that exist in the State of Mexico have allowed SEI to orderly and effectively enact the portal, at least in part, because all public managers know the processes, regulations, guidelines, and actors required for the development and management of the portal.

\section{5. Contextual Factors}

Context is very important for IT projects in the public sector. One of the factors that may affect the website is the socio-demographic characteristics of citizens. The State of Mexico surrounds the Federal District (Mexico City), which is the capital of the country of Mexico. The State of Mexico has the second strongest state economy in the country (among 32 states) and represents $9.2 \%$ of the national GDP. The State of Mexico also has consolidated political power; only one party has ever ruled and they have never had a transition of political party leadership.

An external factor mentioned in the interviews was the culture among citizens with respect to technology, and particularly strong fears about fraud when making online payments for procedures. According to some of the interviewees, between eight and ten percent of all taxes are collected through the portal. Citizens will print the relevant forms, but often prefer waiting in line at bank branches (rather than completing those transactions more quickly online) so that they have physical proof of their payment.

The expansion of social media is a factor that has influenced the portal, as citizens have demonstrated greater interest in participating in government. Public managers commented that the use of social media helps them to better understand the needs of citizens. Regarding external factors that influence the portal, from the standpoint of some interviewees the leadership of the governor directly affects the state development plan and thus the content displayed on the portal.

\section{Discussion and Implications}

This section discusses our findings and contrasts them with existing literature. It also provides some practical and theoretical implications of the study.

\subsection{Leadership of the Governor}

As mentioned early in this paper, politicians play a very important role in the implementation of IT initiatives in the public sector (Gil-García, 2012b). During several of the interviews, the leadership of the governor appeared as one of the factors that significantly affected the construction and strategies of the portal. In general, interviewees agreed that the governor played an important role because he requested that various government secretaries improve the information and services they were offering online. Governor Enrique Peña Nieto wanted to create an integrated portal that could provide citizens with services from any state agency. Subsequently, the current governor, Eruviel Avila, has further promoted the use of technology, particularly social media, and the state has prepared guidelines for the agencies to design digital strategies. It is clear that political leadership was very important to the enactment of technology, which is consistent with prior research (Criado et al., 2010). However, leadership alone is not enough and creating an organizational structure and some standards were also key for the State of Mexico.

\subsection{SEI as a Powerful Centralized IT Agency}

SEI was the agency responsible for the selection of all the technology and infrastructure that state agencies use. They were also responsible for coordinating all the agencies in order to make decisions about technology and content for the portal, which was highly complex given the number of agencies and individuals involved. SEI was able to identify the processes necessary to build a portal and assigned responsibilities to each agency. They also generated the necessary regulations to facilitate activities and collaboration among multiple agencies. In addition to the development of the portal, SEI was constantly searching for improvements, supporting other agencies as they uploaded their information, and providing advice about design strategies and the best use of technological resources.

SEI must also respond to citizens' requests, so they need to have a clear understanding of the different programs and services offered by other agencies. For some of the interviewees, this was a challenge that required good communication and coordination with many individuals across multiple agencies in order to manage the portal and keep it up-to-date. Among other challenges, SEI must establish itself as a formal authority figure that can request information from other agencies and ensure their cooperation.

One interviewee mentioned SEI began as an agency far removed from citizens, but now they receive feedback directly from citizens so that they can improve services, which has made them more sensitive to the specific needs of the public. SEI is a key figure in the success of the portal of the State of Mexico and 
could be considered the most central actor in the network of agencies responsible for the website.

\subsection{Rules and Standards for All Processes and Systems}

According to recent research, some of the main goals in using technology are cost reduction, increased efficiency, improved service quality, greater accountability, and greater citizen participation (Bwalya et al., 2012; Helbig et al., 2009; SandovalAlmazán \& Gil-García, 2008). Most of these goals require agencies to collaborate and share information, which have been identified as difficult tasks (GilGarcia, 2012b).

The portal falls under the responsibilities of the Secretary of Finance. In addition, SEI, a unit that establishes rules and procedures for the portal, also sits under the Secretary of Finance. The state portal is ultimately built with information from various agencies with different goals and multiple stakeholders. Frequently, these agencies do not have good communication with each other, which results in lack of coordination and delays. Similar situations have been found in previous literature related to interagency collaboration (Theresa, Gil-García, \& Burke, 2009). However, the State of Mexico has overcome these challenges through the use of common rules and standards.

SEI has proposed detailed rules and standards for all processes related to the portal. To generate these guidelines, best international and national practices are reviewed and then used to generate an efficient design of procedures and services to ensure successful implementation and a high level of quality. SEI has been able to adapt these best practices to the cultural, national, political, and administrative environment of the State of Mexico.

In general, these rules also allow SEI to have a library of standard frameworks for developing IT projects. They have manuals for agencies that provide a service through the portal. These rules and standards are made with the intention of giving greater flexibility to the agencies involved. Standard processes help to ensure that services will be performed in the same way and with the same quality; this is particularly important since the portal has more than 255 sites embedded within it. The creation of government-wide rules and standards does add to the institutional arrangements that the portal management team needs to consider (Gil-Garcia, 2012a), but ultimately these rules help reduce time, improve coordination, and strengthen control of the portal processes.

\section{Conclusions}

This paper analyzes the case of the State of Mexico's online portal and provides evidence on the importance of multiple factors collectively affecting the success of digital government initiatives. It shows how the political leadership of the governor and other high-level actors is important for success. But also how having an agency that centralizes control of the portal helps to implement the vision of the leaders and provide well-managed, organized, and updated information and services that are accessible to citizens. Finally, one of the most important aspects in this case is the establishment of government-wide rules and standards that help the various agencies involved to do their jobs better and more independently because they clearly understand the structure and requirements of the portal. The centralized IT agency was key in the development and enforcement of many of these standards. Currently, the State of Mexico portal is one of the best in the country and all three of these factors, jointly and individually, have been important for its success. There are also areas for improvement, however, such as the limited mobile government capabilities and apps.

This study focuses on the functionality of the portal and the organizational and institutional variables affecting it. There is little information about the specific technologies the State of Mexico is using as innovations. For instance, future research could explore the content management system that is linked to a knowledge management system, which has allowed SEI to retain information from previous versions of their websites--an uncommon feature for government portals. This is an interesting innovation and other governments could learn from them.

Coordination and collaboration were two important concepts that deserve further investigation. It would be interesting to know in detail how the different units within SEI coordinate among themselves and with other agencies for the portal and other activities related to information technologies in the state. Understanding the different mechanisms of collaboration and the actors involved in each specific activity would help to generate new knowledge about the differences and similarities between different types of collaboration within the same network of actors.

In addition, it seems that some of the organizations involved in the portal are not always performing their formal duties, but are instead serving other functions that are not formally assigned to them. For example, there is a Department of Marketing and Portal Design, but, for some reason, it completes other activities within SEI and not the ones for which it was created. Future research could try to understand goal displacement in cases of digital transformation and 
identify in which instances certain organizations take on different responsibilities.

Finally, the portal is a tool that allows citizens to interact with government directly. To a certain extent, the portal and the network around its creation and management have made the agencies change their structure and decision-making processes. It has forced them to have increased interactions with other agencies and with citizens. More research is needed in terms of understanding government portals as new institutional actors that affect the current governance structures and foster new collaborations and interactions.

\section{Acknowledgements}

This research was partially supported by the Consejo Nacional de Ciencia y Tecnología (CONACYT) in Mexico under grant No. 107154. Any opinions expressed in this document are those of the authors and do not necessarily reflect the views of CONACYT.

\section{References}

Ahn, M. J., \& Berardino, M. (2014). The Adoption of Web 2.0 by the State Government: The Role of Political Environment and Governors. International Journal of Public Administration in the Digital Age, 1(1), 56-73.

https://doi.org/10.4018/ijpada.2014010104

Angoitia, R. (2007). La evolución de los portales de gobierno federal: la experiencia de ocho dependencias (Documento de Trabajo No. 196). México: Centro de Investigación y Docencia Económicas.

Brayda, W. C., \& Boyce, T. D. (2014). So you Really Want to Interview Me?: Navigating "Sensitive" Qualitative Research Interviewing. International Journal of Qualitative Methods, 13(1), 318-334. https://doi.org/10.1177/160940691401300115 Bwalya, K., Zulu, S., Grand, B., \& Sebina, P. (2012). eGovernment and Technological Utopianism: Exploring Zambia's Challenges and Opportunities. Electronic Journal of EGovernment, 10(1), 16-30.

Criado, I., Gascó, M., \& Jiménez, C. (2010). Bases para una Estrategia Iberoamericana de Interoperabilidad. Presented at the XII Conferencia Iberoamericana de Ministros de Administración Pública y Reforma del Estado, Buenos Aires, Argentina. Duhamel, F., Gutiérrez-Martínez, I., Picazo-Vela, S., \& LunaReyes, L. (2014). IT outsourcing in the public sector: a conceptual model. Transforming Government: People, Process and Policy, 8(1), 8-27. https://doi.org/10.1108/TG-05-20130012

Fountain, J. (2001). Building the Virtual State. Information Technology and Institutional Change. Washington, D.C: Brookings Institution Press.

Fountain, J. (2013). Construyendo el Estado Virtual: Tecnologías de Información y Cambio Institucional. (Primera Edición en Español). México, D.F: Centro de Investigación y Docencia Económicas.

Gil-García, J. R. (2012). Enacting Electronic Government Success: An Integrative Study of Government-wide Websites,
Organizational Capabilities, and Institutions. (Springer). New York, NY.

Gil-García, J. R. (2013). Estudio Introductorio: La Teoría de la Promulgación de la Tecnología para Entender y Mejorar Iniciativas de Gobierno Digital. In J. Fountain, Construyendo el Estado Virtual: Tecnologías de Información y Cambio Institucional (Building the Virtual State: Information Technology and Institutional Change). (Primera Edición en Español., pp. 1957). México, D.F: Centro de Investigación y Docencia Económicas.

Gil-Garcia, J. R., Chengalur-Smith, I., \& Duchessi, P. (2007). Collaborative e-Government: Impediments and benefits of information-sharing projects in the public sector. European Journal of Information Systems., 16(2), 121-133.

Gil-García, J. R., \& Dawes, S. (2007). The New York State Website: Accommodating Diversity through a Distributed Management Structure. In B. Rocheleau (Ed.), Case Studies in Digital Government. (pp. 230-246). Estados Unidos: Idea Group Inc.

Heeks, R. (2003). Most eGovernment-for-Development Projects Fail: How Can Risks be Reduced? (No. 14). Manchester: Institute for Development Policy and Management. Retrieved from

http://www.sed.manchester.ac.uk/idpm/research/publications/wp /igovernment/documents/igov_wp14.pdf

Luna-Reyes, L. F., \& Gil-Garcia, J. R. (2014). Digital government transformation and internet portals: The coevolution of technology, organizations, and institutions. Government Information Quarterly, 31(4), 545-555. https://doi.org/10.1016/j.giq.2014.08.001

Luna-Reyes, L. F., Hernández-García, J. M., \& Gil-García, J. R. (2009). Hacia un Modelo de los Determinantes de Éxito de los Portales de Gobierno Estatal en México. Gestión y Política Pública, XVIII(2), 307-340.

Management Association, I. R. (Ed.). (2015). Public Affairs and Administration: Concepts, Methodologies, Tools, and Applications. IGI Global. https://doi.org/10.4018/978-1-46668358-7

Mercado-Lara, E., \& Gil-García, J. R. (2014). Gobierno Abierto e Intermediarios de Datos: El Caso de AidData. (Documento de Trabajo No. 289). Centro de Investigación y Docencia Económicas. Retrieved from http://www.cide.edu.mx/publicaciones/status/dts/DTAP\%20289. pdf

Noveck, B. (2009). Wiki Government: How Technology Can Make Government Better, Democracy Stronger, and Citizens More Powerful. Estados Unidos: Brookings Institution Press. Sáez Martín, A., Rosario, A. H. D., \& Pérez, M. D. C. C. (2016). An International Analysis of the Quality of Open Government Data Portals. Social Science Computer Review, 34(3), 298-311. https://doi.org/10.1177/0894439315585734

Sandoval-Almazán, R., \& Gil-García, J. R. (2008). Evolución de los Portales Estatales de Gobierno Electrónico en México 20052007. In J. L. Becerra (Ed.), El que Manda: El Ciudadano. México: Comité de Informática para la Administración Pública Estatal y Municipal (CIAPEM) (pp. 63-89). México.

Thomas, M. A., \& Alalwan, J. A. (2016). Designing a Semantic Tool to Evaluate Web Content of Government Websites: International Journal of Public Administration in the Digital Age, 3(2), 19-36. https://doi.org/10.4018/IJPADA.2016040102 